\title{
In Vitro Bulb Regeneration from Stem Explants of Endemic Geophyt Muscari aucheri (Boiss.) Baker
}

\author{
Fethi Ahmet ÖZDEMİ *1, Ömer KILIÇ ${ }^{2}$, Eyüp BAĞCI ${ }^{3}$ \\ ${ }^{1}$ Department of Molecular Biology and Genetics, Faculty of Science and Art, Bingol University, Bingol, Turkey \\ ${ }^{2}$ Bingol University, Technical Science, Vocational College, Bingol, Turkey \\ ${ }^{3}$ Department of Biology, Faculty of Science, Firat University, Elazıg, Turkey
}

Received: 29 April 2017 - Revised: 17 June 2017 - Accepted: 30 June 2017

\begin{abstract}
Muscari aucheri (Boiss.) Baker bears beautiful and attractive purplish blue flowers bloom between May and June; it grows stony slopes, mountain pastures an altitude of 1000-3000 meters. The natural populations of Muscari aucheri, is seriously affected by increased environmental pollution, urbanization and grazing. Therefore, this study aimed to accelerate multiplication by devising a strategy for an efficient in vitro bulblet regeneration system of Muscari aucheri using stem explants on MS medium containing 1, 3, $5 \mathrm{mg} / \mathrm{TDZ}$ plus $0,0.1,0.2,0.4$ $\mathrm{mg} / \mathrm{l}$ NAA (12 combinations). The stem explants induced direct bulblet regeneration on explants. Maximum mean number of bulblets per explant was noted on MS medium containing $3 \mathrm{mg} / \mathrm{l} \mathrm{TDZ}+0.4 \mathrm{mg} / \mathrm{l} \mathrm{NAA}$ and maximum mean number of bulb diameter was noted on MS medium containing $5 \mathrm{mg} / \mathrm{l} \mathrm{TDZ}+0.2 \mathrm{mg} / \mathrm{l} \mathrm{NAA}$. The regenerated bulblets were isolated from stem explants and cultured on MS medium containing $40 \mathrm{~g} / \mathrm{l}$ sucrose; where they gained diameter and rooted
\end{abstract}

Keywords: Muscari aucheri, in vitro, bulb regeneration

\section{INTRODUCTION}

Because of important location of Turkey has created a diversity of climates, habitats and ecosystems that has resulted in extraordinary plant diversity of above 13.000 native vascular plants. At least 3025 (33\%) taxa among them are endemic, about 2222 endangered and 585 as vulnerable or critically endangered. Most of the vulnerable geophythes belong to Liliaceae, Amaryllidaceae and Iridaceae families [1]. Bingol also has a very rich flora and many endemic species and the main reasons of this richness are its geomorphologic features, microclimate and habitat diversities. The genus Muscari Mill. includes nearly 61 taxa distributed in the world and its members mostly occur in the whole Mediterranean basin as far as the Caucasus, temperate Europe, North of Africa and South West of Asia [2]. In Flora of Turkey Muscari has about 30 taxa and the endemism rate in this genus is consequently very high, about $60 \%$ [3]. Endemic Muscari aucheri is most fragrant plant among Muscari taxa and has high ornamental potential [3]. Ten species of Muscari including ornamental M. aucheri are endemic or vulnerable and has concolorous flowers [4]. The natural populations of $M$. aucheri, is seriously affected by

*Corresponding Author E-mail: ozdemirfethiahmet23@yahoo.com

ISSN: 2148-6905 online /C 2017

DOI: $10.21448 /$ ijsm. 356264 
increased environmental pollution, urbanization and grazing. $M$. aucheri bears beautiful and attractive purplish blue flowers bloom between May and June; it grows stony slopes, mountain pastures an altitude of 1000-3000 meters [5]. A number of Muscari species are used as ornamental garden plants. However, commercial propagation especially micropropagation of $M$. aucheri has to be advanced. Nowadays, due to number of abiotic and biotic stresses $M$. aucheri populations are under great pressure at its habitat. For example, some Muscari species has been included in the list of export prohibited plant species [4]. So there is urgent need to production with micropropagation method that should serve effectively for commercial propagation and conservation of geophytes, especially endemic $M$. aucheri.

The present investigation is a preliminary study. Extension of this study purposely may help in multiplication of this plant with unrestricted and safe availability of M. aucheri throughout the year. Therefore, this study aimed to develop and optimise a bulblet regeneration protocol using stem explants.

\section{MATERIAL and METHODS}

\subsection{Plant Material and Sterilization}

M. aucheri were collected from Bingol-Center, above Alatepe village, vicinity of Firın river, plateau, stony slopes, 1800-1900 m. The plants were identified based on "The Flora of Turkey and East Aegean Islands, volume 8"[6]. The voucher specimens are deposited at the herbarium of the Department of Biology, Hacettepe University Ankara and the Department of Park and Garden Plants of Bingol University, Turkey. Before starting the experiment, the stems from the plants were washed under running tap water for $30 \mathrm{~min}$ to remove all adhering contaminants. Thereafter, stems of these plantlets were treated with $35 \% \mathrm{H}_{2} \mathrm{O}_{2}$ solution for 30 min under aseptic conditions followed by $5 \times 5$ min rinsing with sterilized distilled water. Thereafter, $\sim 0.5 \mathrm{~cm}$ long stems explants were excised aseptically.

\subsection{Culture Conditions}

All explants were cultured in petri dishes on $0.65 \%(w / v)$ plant agar (Duchefa) solidified MS medium [7] containing 1, 3, $5 \mathrm{mg} / 1 \mathrm{TDZ}$ plus $0,0.1,0.2,0.4 \mathrm{mg} / \mathrm{l} \mathrm{NAA}$ (12 combinations) supplemented with $3 \%$ sucrose to regenerate bulblets. A control was also planted on MS medium supplemented with $3 \%$ sucrose without growth regulators. The $\mathrm{pH}$ of all media was adjusted to 5.6 with $1 \mathrm{M} \mathrm{NaOH}$ or $1 \mathrm{M} \mathrm{HCl}$ and media were autoclaved for 20 min at $120^{\circ} \mathrm{C}$, $1.4 \mathrm{~kg} \mathrm{~cm}^{-2}$. Unless otherwise stated, all cultures were maintained under $16 \mathrm{~h}$ light/ $8 \mathrm{~h}$ dark photoperiod $\left(35 \mu \mathrm{mol} \mathrm{m} \mathrm{m}^{-2} \mathrm{~s}^{-1}\right)$ in versatile growth chamber at $24 \pm 1^{\circ} \mathrm{C}$.

\section{RESULTS and DISCUSSIONS}

The present investigation was carried out to optimize micropropagation and fast multiplication protocol from stems explants of $M$. aucheri. All stems explants regenerated bulblet on MS medium five months after culture initiation. The results showed that the combinations and rates of TDZ and NAA sharply affected bulblet regeneration percentage. Bulblets regeneration percentage ranged between $100.0 \pm 0.3$ to $36.4 \pm 0.71 \%$ (Table 1 ). Furthermore, equal to or over $60.3 \pm 0.5 \%$ bulblet regeneration was noted on 6 treatments. The highest bulblet regeneration percentage was obtained on MS medium containing $3 \mathrm{mg} / \mathrm{TDZ}+$ $0.4 \mathrm{mg} / 12 \mathrm{NAA}$ (Fig 1 a) followed very closely by MS medium containing $5 \mathrm{mg} / \mathrm{l} \mathrm{TDZ}+0.4$ mg/l NAA. The results further showed that combinations and rates of plant growth regulators used in the study also affected the mean number of bulblets per explant. The stems explants were found very suitable for bulblet regeneration. Bulblets were induced directly on the stems explants (Fig $1 \mathrm{~b}, \mathrm{c}, \mathrm{d}$ ). The mean number of bulblets per explant ranged between $37.3 \pm 0.8$ to $9.7 \pm 0.4$. The maximum mean number of bulblets per explants (37.3 \pm 0.8$)$ were recorded on MS 
medium containing $5 \mathrm{mg} / \mathrm{l} \mathrm{TDZ}+0.20 \mathrm{mg} / \mathrm{l} \mathrm{NAA}$. It was followed by a significantly reduced number of $22.7 \pm 0.6$ bulblets per explant on MS medium containing $5 \mathrm{mg} / \mathrm{TDZ}+0.1 \mathrm{mg} / \mathrm{l}$ NAA (Table 1).

Table 1. Effect of different concentrations of TDZ + NAA on MS medium on bulblet regeneration from stems explants of M. aucheri.

\begin{tabular}{ccccc}
\hline $\begin{array}{c}\text { Growth Regulators } \\
\text { IDZ(mg/l) NAA(mg/l) }\end{array}$ & $\begin{array}{c}\text { Bulblet regeneration } \\
\text { percentage }(\%)\end{array}$ & $\begin{array}{c}\text { Mean number of bulblets } \\
\text { per explant }\end{array}$ & $\begin{array}{c}\text { Mean bulblet } \\
\text { diameter }(\mathbf{c m})\end{array}$ \\
\hline \multicolumn{2}{r|}{ VS medium (control) } & $0.0 \pm 0.0$ & $0.0 \pm 0.0$ & $0.0 \pm 0.0$ \\
1 & 0 & $36.4 \pm 0.71$ & $11.6 \pm 0.2 \mathrm{j}$ & $0.1 \pm 0.0 \mathrm{c}$ \\
3 & 0 & $38.3 \pm 0.4 \mathrm{k}$ & $9.7 \pm 0.41$ & $0.1 \pm 0.0 \mathrm{c}$ \\
5 & 0 & $42.6 \pm 1.2 \mathrm{j}$ & $12.3 \pm 0.7 \mathrm{i}$ & $0.1 \pm 0.0 \mathrm{c}$ \\
1 & 1.1 & $46.7 \pm 0.5 \mathrm{i}$ & $17.6 \pm 0.5 \mathrm{e}$ & $0.2 \pm 0.1 \mathrm{~b}$ \\
3 & 1.1 & $50.3 \pm 0.1 \mathrm{~h}$ & $10.3 \pm 0.3 \mathrm{k}$ & $0.2 \pm 0.2 \mathrm{~b}$ \\
5 & 1.1 & $52.7 \pm 0.1 \mathrm{~g}$ & $22.7 \pm 0.6 \mathrm{~b}$ & $0.3 \pm 0.1 \mathrm{a}$ \\
1 & 1.2 & $60.3 \pm 0.5 \mathrm{f}$ & $14.6 \pm 0.8 \mathrm{f}$ & $0.2 \pm 0.1 \mathrm{~b}$ \\
3 & 1.2 & $66.6 \pm 1.0 \mathrm{e}$ & $18.7 \pm 0.3 \mathrm{~d}$ & $0.1 \pm 0.1 \mathrm{c}$ \\
5 & 1.2 & $68.3 \pm 0.4 \mathrm{~d}$ & $37.3 \pm 0.8 \mathrm{a}$ & $0.1 \pm 0.2 \mathrm{c}$ \\
1 & 1.4 & $72.7 \pm 0.7 \mathrm{c}$ & $14.6 \pm 0.5 \mathrm{~g}$ & $0.1 \pm 0.1 \mathrm{c}$ \\
3 & 1.4 & $100.0 \pm 0.3 \mathrm{a}$ & $13.3 \pm 0.3 \mathrm{~h}$ & $0.2 \pm 0.1 \mathrm{~b}$ \\
5 & 1.4 & $84.6 \pm 0.4 \mathrm{~b}$ & $21.7 \pm 0.7 \mathrm{c}$ & $0.2 \pm 0.2 \mathrm{~b}$ \\
\hline
\end{tabular}

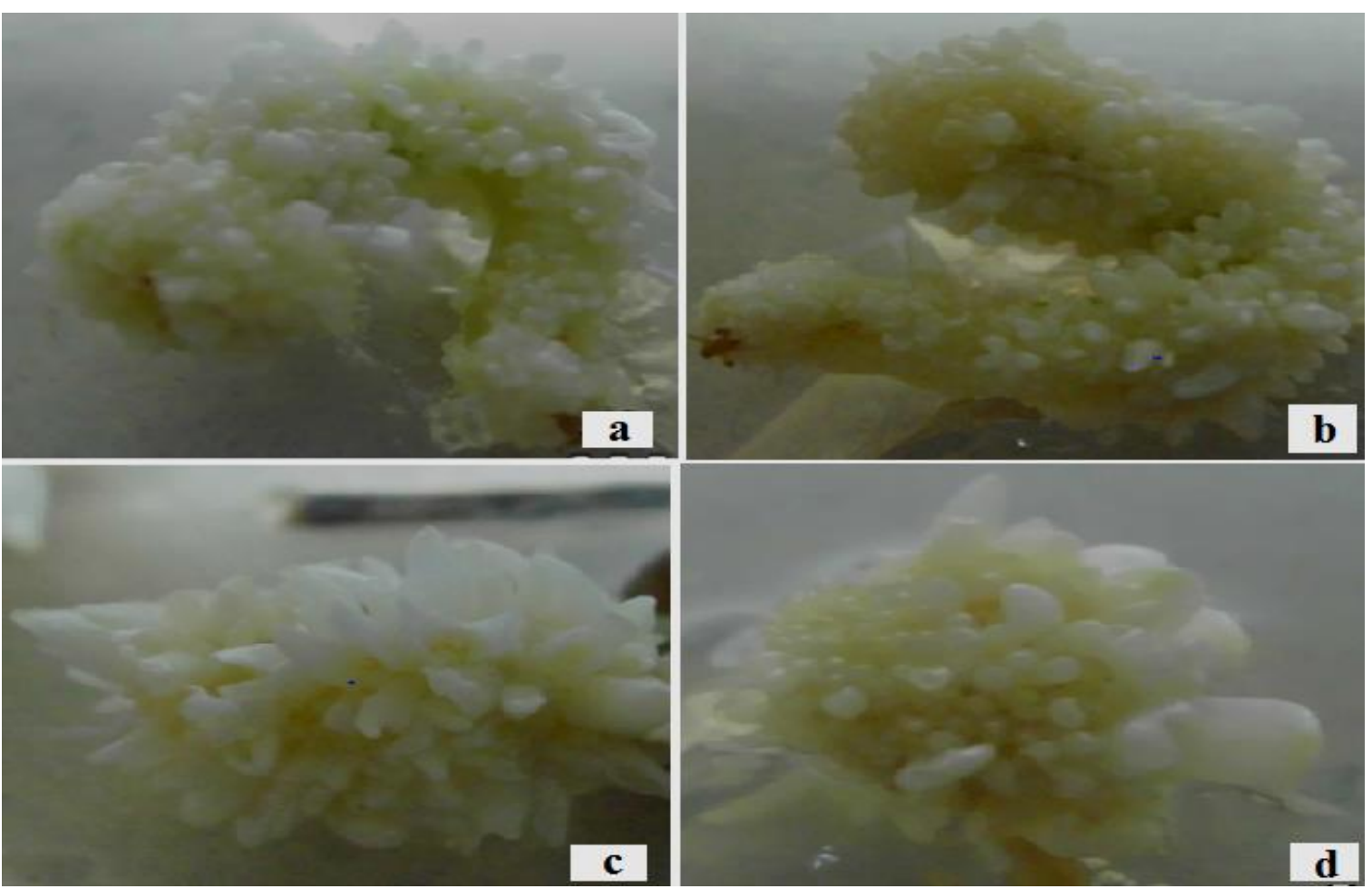

Figure 1. Bulblet regeneration on stems explant of $M$. aucheri. (a) using MS medium containing $3 \mathrm{mg} / \mathrm{lDZ}+$ $0.4 \mathrm{mg} / \mathrm{l}$ NAA (b), developing and growing bulblets on MS medium (Bar Fig $1 \mathrm{a}, \mathrm{b}, \mathrm{c}, \mathrm{d}=0.3 \mathrm{~cm}$ ).

Mean bulblet diameter varied in the range of $0.3 \pm 0.1$ to $0.1 \pm 0.0$ (Table 1 ). The maximum mean bulblet diameter $(0.3 \pm 0.1 \mathrm{~cm})$ was recorded on MS medium containing $5 \mathrm{mg} / 1 \mathrm{TDZ}+0.1$ $\mathrm{mg} / \mathrm{l}$ NAA. Bulblet diameter equal to $0.10 \mathrm{~cm}$ or above was recorded for 6 treatments. It was noted that the bulblets induced a positive increase in bulblet diameter on culturing on MS 
medium containing $40 \mathrm{~g} / \mathrm{l}$ sucrose, where they induced a bulblet diameter. Plant tissue culture techniques provide possibility to introduce new approaches for direct regeneration depending on strong [8]. The major problem to regeneration from any plant could be right choice of the explants and plant growth regulator combinations. In vitro micropropagation of $M$. aucheri is very important and needs attention for development of micropropagation system for commercial use. MS medium supplemented with 12 different combinations of TDZ plus NAA provided profuse and high percentage shoot regeneration on stems explant used in this study. The results of this study showed that use of stems explants for the micropropagation of $\mathrm{M}$. aucheri may have great value. Previous studies on other bulbous plants $[9,10]$ recorded that the media containing TDZ induce positive effects on regeneration capacity.

Results of the present study agreement with these sudies. Also TDZ did not effectively promote bulblet regeneration in M.aucheri [11]. Results of the present study differ from this study, the contrasting results may be related with different endogenous plant growth regulators in explants obtained from different types of geophyte species used in the above mentioned reports. But are in agreement with Huetteman and Preece (1993) who reported that TDZ increased bulblet regeneration [12]. In the present study high bulb regeneration was obtained with media using $3 \mathrm{mg} / \mathrm{l} \mathrm{TDZ}+0.4 \mathrm{mg} / \mathrm{l} 2$ NAA. Similarly Nasircilar et al., (2011) reported positive increase in mean number of bulb regeneration when TDZ was used with NAA [13]. Our results agreement with this finding and showed efficient bulblet regeneration from stems explants using TDZ + NAA. The concentration of TDZ or NAA in the culture medium was found to have a critical role for bulblet regeneration. Suzuki and Nakano (2001) showed that the importance of NAA on bulb regeneration in culture medium [14]. This finding agreement that NAA increase in culture medium, increase bulblet regeneration too. The findings of the study confirm that the stems can be used successfully as explants and can form an alternative source for regeneration without destruction of stock plant and positively evaluate potential of expediently isolated explants from inflorescence stems for an efficient micropropagation.

\section{CONCLUSION}

In conclusion, culturing stems explants on MS medium containing BAP and NAA is an effective method for in vitro propagation of $M$. aucheri. This method can be used for propagation and conservation of endemic $M$. aucheri.

\section{Acknowledgement}

The authors acknowledge the Scientific and Research Council of Bingol University (BAP TBMYO.2016.00.001) for support this study.

\section{Conflict of Interests}

Authors declare that there is no conflict of interests.

\section{REFERENCES}

[1] Ekim, T. (2006). Türkiye'nin bitkileri. Türkiye’nin Önemli Doga Alanları. Doga Dernegi, Ankara, Turkey, 47-48.

[2] Jafari, A., Maassoumi, A.A., \& Farsi, M. (2008). Karyological study on Bellevalia and Muscari (Liliaceae) species of Iran. Asian Journal of Plant Sciences, 7, 50-59.

[3] Demirci, S., Özhatay, N., \& Koçyiğit, M. (2013). Muscari erdalii, a new species from Southern Turkey. Phytotaxa, 154, 38-46.

[4] Ekim, T., Koyuncu, M., Vural, M., Duman, H., Aytac, Z., \& Adiguzel, N. (2000). Türkiye Bitkileri Kırmızı Kitabı. Turkiye Tabiatını Koruma Dernegi Yayınları, Ankara.

[5] Anonim, www.tubives.com 
[6] Davis, P.H., (1984). Flora of Turkey and East Aegean Islands, University Press, Edinburgh, 8.

[7] Murashige, T., \& Skoog, F. (1962). A revised medium for rapid growth and bioassays with tobacco tissue cultures. Physiologia Plantarum, 15, 473-497.

[8] Ochatt, S.J., Conreux, C., \& Jacas, L. (2013). Flow cytometry distinction between species and between landraces within Lathyrus species and assessment of true-to-typeness of in vitro regenerants. Plant Systematic Evoluation, 299, 75-85.

[9] Malabadi, R.B., \& Van Staden, J. (2004). Regeneration of Ornithogalum in vitro. South African Journal of Botany, 70, 618-621.

[10] Suh, J., Lee, W., \& Lee, A. (2005). New plantlet proliferation and bulbing promotion in vitro cultures of Ornithogalum hybrid. Acta Horticulturae, 683, 155-163.

[11] Uranbey, S. (2010). Stimulating effects of different basal media and cytokinin types on regeneration of M. aucheri. Archives Biological Sciences, 62, 663-667.

[12] Huetteman, C.A., Preece, J.E. (1993). Thidiazuron: a potent cytokinin for woody plant tissue culture. Plant Cell, Tissue and Organ Culture, 33, 105-119.

[13] Nasircilar, A., Mirici, S., Karagüzel, Ö., Eren, Ö., \& Baktir, I. (2011). In vitro propagation of Muscari mirum from different explant types. Turkish Journal of Botany, 35, 37-43.

[14] Suzuki, S., Nanako, M. (2001). Organogenesis and somatic embryogenesis from callus cultures in Muscari armeniacum. Leichtl. ex Bak. In vitro Cell, 37, 382-387. 